\title{
POST-SOCIALIST LANDSCAPE: A CASTLE BY THE ROAD
}

MIŠO KAPETANOVIĆ

1200 Vienna, Othmargasse 36/8

Austria
DOI: $10.17234 /$ SEC.27.12

Preliminary communication /

Prethodno priopćenje

Received / Primljeno: 1 March 2015

Accepted / Prihvaćeno: 3 November 2015

This article explores the proliferation of private housing and business objects along major roads that are modelled to resemble castles. I am interested in the changes these structures make in landscape, the new qualities they bring to the surroundings and the meanings they connote. From a first glance at their flamboyant, surreal and naïve forms it is evident that the structures represent nostalgia, exotic places and fantasies. By employing photography based semiotic analysis I seek to discover how these structures visually convey post-socialist and postwar perspectives and how their stories are connected to the new modernity rising around them.

Keywords: roadscape, Post-Socialist, nostalgia, imitation, post-tourism

"Tourists seeking casinos and kitschy public versions of traditional culture will greatly outnumber and outspend those seeking authenticity." (Harkin 2003:583)

Several years ago, some friends from North America and Australia took part in a student workshop in Mostar, Bosnia and Herzegovina. Having worked in the city for several years before that, I enthusiastically directed them to some points of interest. However, when they returned excited and happy about the trip, looking at the photographs they took left me in silent discomfort of, what I would later find out, is sometimes called ruin porn (Leary 2011). Out of all the potential sites in Mostar, from the Old Bridge and traditional houses, narrow streets and dusty barber shops, to new bars, clubs and shopping malls, including a semi-ironic Bruce Lee statue, and the excitable and loud people in what I felt was a vibrant Mediterranean town, they ended up photographing mostly war ruins. I wasn't able to express my disappointment, as their photographs were a fairly accurate portrait of the divided town, torn by the early 1990s conflict and post-war politics of ethnic segregation. However, I could not stop myself from fighting the feeling that this was not all of it; that this was not how I used to experience and remember Mostar. 
To some extent, the attraction of Mostar's ruins is representative of the entire country. There is dynamic and extensive discussion over the wider context of changes that occurred during the war and its consequences. This discussion has not been followed up, at least not to the same degree, with debate on what has changed after the war independently of the ethnic conflict, or how society is experiencing and responding to such changes. To name just a few, over the last two decades, technologies of communication and knowledge have radically changed with the Internet and cheap affordable smartphones and personal computers; technologies of mobility have become as available (if not always affordable) as second hand cars and, somewhat later, cheap flights entered the market, while public bus companies were privatised, their services divided up between local firms. The state lost the presence it had previously held in many parts of private life, especially those not directly connected with national interests, for example, in supervising the private construction which resulted in an explosion of informal buildings. As most of these changes were simply beyond the ethno-nationalist focus, their effects and people's responses to them remain largely undocumented and under-researched.

During the post-war reconstruction process and the later explosion of informal construction ${ }^{1}$ there was a profusion of flamboyant and extravagant forms and decorations in vernacular housing ${ }^{2}$. After the war, houses were

${ }^{1}$ Informal construction was in the context of late socialist Yugoslavia often conveyed as Illegal construction, framing the phenomenon primarily through its legislative dimension, or building objects without permission or consulting urban development plans (Bežovan and Dakić 1990; Kos 1993), but its scale significantly increased after the war.

2 The terms "vernacular" and vernacular construction were in local literature primarily explored through ethnographic interest in traditional housing of specific regions. Respectful to this tradition, the qualification "Yugoslav vernacular house" used later in this text might appear as unnecessary generalisation, but I would insist on using it to describe prevalent model of private housing prevalent in both urban and rural environments that rose from specific needs of Yugoslav socialist modernism. Therefore the syntagm Yugoslav vernacular house will be used to describe cheap private housing, simplified version of traditional vernacular models built with modern materials and mass produced throughout the whole former state. While the first mentioned traditional models of regional vernacular housing were well explored, the modernised version was systematically ignored due their ambiguous modern, but common character. 
not just rebuilt, they were also radically redesigned. Almost all of them are decorated naïvely, but daringly, by applying bright colours incoherent with the surroundings, using random elements on façades and generally having unpredictable completion dates. Due to a lack of correspondence with professional architecture, professionals ignore them, while the media register them peripherally, by ridiculing them and reducing them to kitsch. However, these funny, vulgar, brightly coloured buildings cannot be seen only for their lack of taste, if nothing more because they are present on a massive scale which is transforming the landscape.

By analysing the visual language of these buildings, I look at how visual expressions of them are changing the meanings of the spaces around them and the ways in which we perceive Bosnia and Herzegovina in general. In order to answer this question I focus on the road and extravagant roadside housing ${ }^{3}$ constructions, asking: how do they engage with road users? How do they compose representations and what do their specific compositions seek to represent? How does this relate to larger social processes around them, and how do they reflect larger global changes occurring in peripheries such as Bosnia and Herzegovina? To answer these questions I take a strictly post-socialist perspective, through which I employ the concept of landscape, an analytical tool traditionally used in cultural geography. I narrow this concept to roadscape, the landscape viewed from a moving car, and apply it to four specific examples of extravagant houses. Documenting the houses with photography I understand them as centres of new Bosnian roadscapes and apply a semiotic analysis to ascertain what their representations are communicating.

\section{GAZING INTO THE LANDSCAPE}

Two major events are important in understanding the recent history of the country. The country declared independence from the former Socialist

\footnotetext{
${ }^{3}$ The buildings analysed here had their function extended from private housing to hospitality and catering for other small businesses, but as their formal structure still strongly refers to above described housing model, therefore in further text they will still be referred as houses.
} 
Federal Republic of Yugoslavia in 1992, a declaration which was followed by an armed conflict between several local and foreign military formations representing the major three ethnic groups in the country (and the proxies of neighbouring Serbia and Croatia) and resulting in large devastation and genocide against Bosniaks (Hoare 2007). Besides this devastating conflict, the country also entered into a transformation from a socialist economy and a single party system within a larger federal state to a market economy and democracy within the state of Bosnia and Herzegovina now set as a defacto confederation itself. Almost twenty years after these major changes occurred, the citizens are still preoccupied with the legacy of war and ethnic conflict while post-war perspectives ${ }^{4}$ arguably play a much more important role than post-socialist (Gilbert 2006). Considering the large scale of the atrocities that the war has caused, this is somewhat understandable, but still in dissonance with other post-socialist societies. Accordingly, it may be assumed that this discourse has been translated into academic research, which itself heavily relies on different types of discourse analysis. In this way a post-war orientation is perpetuated in contemporary research on Bosnian society in general. I was, therefore, more interested in processes relating to post-socialist transformations rather than the ethnic conflict. By taking this perspective, I am interested in processes common to the entire population of the country, transgressing communal divisions and not being necessarily dependent on ethnicity. The houses with which this paper deals are primarily the consequence of the collapse in socialist orders of planning and providing housing and in organising their aesthetics and visual representations. This perspective certainly does not mean avoiding politics, and ethnicity and genocide should not be avoided, given that they play an important role, for example when a house is clearly displaying nationalist symbols (as evident in the first case presented). But the relevant question for the houses is not how they were destroyed and left ruined. The important question is how their reconstruction visually restructured whole new worlds around them.

4 As these perspectives are to an extent inter-dependent, it is not possible to clearly separate them and it is important to notice that social mobilisations in 2013-2014 (Bosnian spring, JMBG protests) countered a post-ethnic perspective by engaging other political subjectivities (Touquet 2012). 
Originally reserved for natural history and romantic painting, the concept of landscape as an analytical unit was primarily used in cultural geography (Cresswell 2003), though it was not restricted to it. It developed around two main clusters of ideas which based their definition around the picture (Sauer 1965) or the viewer (Meinig 1979). The first understood the landscape as a fixed composition of smaller artefacts, material culture generated by the people living in it (Cresswell 2003:269). The second direction saw landscape as a cultural system, a text in which the social is communicated, experienced, reproduced and explored (ibid. 271). Both these views tended to construct landscape as a static material construct, studied by an outsider. Outside of cultural geography, this problem was dealt with in the works of the cultural studies scholar Raymond Williams (1977) who tried to theoretically frame landscape as interplayed with practice and J. B. Jackson (1997) who steered his understanding of landscape to common ways in which it is experienced, through moving cars and motorbikes, photographs and advertisements, seeing it as dynamic and constantly changing, with the observer immersed within it. A later understanding of landscape as a system, led to the simplification and overuse of the term, which dispersed its analytical potential (Cresswell 2003:276). The overuse of the word in different disciplines did not deplete the analytical potential of the concept, and it enabled valuable contributions to be made in understanding changes on a larger scale, primarily as it works with traces of material culture that are visually recordable and which therefore serve as a good alternative to discursive sources. Landscapes open up the possibility of seeing space as a text, where collective human activity moulds the environment, but also actively involves the researcher while changing over time. Therefore, it may be used as a tool to understand the larger material scale of recent historical changes, such as the end of socialism, in a local setting and how the community responded to it.

On a more specific level, it can serve to bring more dynamism to the understanding of material culture. In landscapes, buildings and other objects are moved, composed and recomposed following specific orders, e.g. sets of ideas. In this process, meanings encoded in them are consequently renegotiated and therefore the landscape functions as a tool to understand individual negotiations that go above individual interactions. What people do in their environments does not always cohere with what 
they say, so landscape can be used to trace what is transgressive and abject, or unspeakable and disgusting (Buchli and Lucas 2001:10-12). In this particular case I was interested in how houses can structure the whole cultural landscape. In the early 1990s it was impossible for one to speak about natural beauties of landscape, next to the sights of war and destruction. Twenty years after the destruction ended, it is perfectly acceptable to fixate oneself on ruins, while newly built and reconstructed buildings, which are often drastically different from those erected prior to the conflict, frequently on a massive scale, are ignored.

On a wider scale, Yugoslav socialist society created specific landscapes, such as the cityscapes of massive urban housing projects (e.g. Alipašino Polje in Sarajevo), the sights of almost gothic industrial facilities (such as industrial zones in Zenica or Kakanj) and gigantic monuments (Sutjeska, Kozara, Mostar's Partizan Memorial Cemetery). Strictly encoded with stylistics and celebrated as glorified specimen of modernism (Kulić and Mrduljaš 2012), most of these landscapes are retreating or restructuring as a consequence of social transformation. As a material expression of transformation, landscapes reaffirm non-linear understandings of postsocialist transformation where market economy and democracy did not guarantee prosperity; but were rather a road to the unknown (Verdery 1996). Current research deals with these topics mainly by exploring their destruction of the urban fabric and the increasingly revisionist politics that came afterwards (Czepczyński 2008; Hirt 2008), as well as non-academic contributions to derelict socialist memorials (Kempenaers and Neutelings 2010) while landscapes of privatisation, abandonment or the destruction of massive industry, rural transformations, mobility and the politics of the body remain under-researched.

The strictly negative angle that followed the destruction and catastrophe can be compared with what John Patrick Leary named ruin porn (2011): a pornographic sensationalism concerning the large scale landscapes of destruction in the city of Detroit. Analog to Detroit, the attraction to death and decay in wider East European context, reduces post-socialist experience to ruin, while new developments that were not destroyed or privatised remain ignored.

Traditionally seen and constructed through painting, photography, and video or in rare occasions in person, landscapes were increasingly 
experienced from cars due to an increase in mobility. Therefore the roadscape, the view of the outside landscape from a moving car, became a common way of consuming the landscape. The concept was coined by Jackson (1984) while researching the modern landscapes during the rise of automobile in the US after World War II. It captures well the new optics in landscape consumption produced by the car (Jackson 1997:149-150), where outside imaging is reduced and simplified as perceived at an average velocity of 60 kilometres per hour. Seen in this way, space exists only in two and a half dimensions, consisting of the roadside objects with a perceptual wall behind them, where details are lost and simpler signs (icons) are perceived more easily than complex ones (symbols). In an increasingly mobile Bosnia and Herzegovina, the roadside became an interesting spot where change is happening quicker than elsewhere. As well, being a completely provisional and unusual research site, it was not burdened with binding research practices connected with post-war perspectives.

The best way to understand and capture the roadscape was to drive. I chose a peculiar route in the north, formally known as "Koridor", formed during the Bosnian war and extensively used for all sorts of traffic, where I drove behind personal cars, delivery vans and trucks and registered houses they were stopping over. During the rides which occurred five-six times per year continuously over the last three years (2012-2014), I photographed and followed the development of a larger number of buildings which were interesting due to their extravagant appearance. Four of these buildings will be presented in this paper. The majority of photographs were taken during the field trips, when I tried to be as unobtrusive as possible and simply record everything that could be seen from the car. In 2014 the photographs were expanded with videos produced by a car camera, which enabled the capturing of more details in the field and their later conversion to photographs. In several field trips I was accompanied by colleagues, including researchers interested in my project or in Bosnia and Herzegovina in general, and I used this opportunity to obtain photographs of the houses taken by them in order to compare a difference in gaze. This step prompted me to search for other admirers of the buildings which could be found in large numbers amongst internet users, mainly in photography WEB 2.0 communities (mostly Panoramio and Google Maps, while Flickr and Tumblr were engaged without results). There were often forum discussions 
on the aesthetic quality of the architecture, next to the photographs of the houses presented, which were used to support my interpretations of the buildings and their roadscapes ${ }^{5}$.

The photographs were analysed through a process of visual recognition, classification and the interpretations of signs based on semiotics as explained by Roland Barthes (1967). As an approach used in Balkan studies, semiotics have been used to explore the politics of signs in public space, including the symbolic change of street names (Radović 2014) or the destruction of books as symbols (Lešaja 2012). However, these processes are tightly connected with ethno-nationalism and therefore more relevant for post-war perspectives rather than a focus on post-socialist transformation.

Semiotic analysis has been employed to identify signs, determine the level of connotation (icons, indexes, symbols), and to interpret possible meanings connoted and examine their correlation with other signs in the composition and in the wider environment (Barthes 1967:90). Signs are, as a basis for human communication, agreed upon, and their connotation is constantly re-negotiated (ibid. 93). Analysing signs is mainly based on interpretation, but the procedure is not fully provisional, since the construction, usage and renegotiation of signs provide social verification (ibid. 95). Therefore the interpretation follows the rules of communication and frames of reference common to the social contexts which employ the signs.

Here, the road is particularly important as the experience of driving in a motor vehicle determines the perception and production of signs with simpler references, icons and indexes. Unfortunately, the prevalence of icons and indexes makes texts appear less articulate, often vulgar and unable to convey complex meanings, characteristic for communication

\footnotetext{
${ }^{5}$ In that manner, affirming landscapes as a unit might lead to conclusion that the analysis will deal with wider environments similar to the landscapes portrayed in classical painting or literature. This will, however, not be the case. Understanding the landscapes as frameworks for observing dynamic environments, and as such category of space, does not limited its scale. Therefore the landscapes analysed here will be framed solely around houses presenting alternative perspective to the professional architecture which rejects these structures as illegal construction.
} 
amongst members of the working class (Bernstein 1964). Rather than there being an actual inability ascribed to working class members in conveying complex meanings, the sense in which iconic texts often seem less articulate and vulgar is a product of an elitist bias amongst the viewers, who are often researchers (Hartley 2012:104-105). Therefore, when dealing with an iconic text, it is important to bear in mind that a composition appearing primitive, vulgar or banal at first sight might actually be the consequence of a viewer's immersion in symbol-oriented compositions common to the upper-class communication of art elites, rather than the composition's inability to convey complex meanings.

While in further text terms like ugly, vulgar, naïve, or banal will be used, the idea behind their usage is not to ascribe low aesthetic value to the houses. While my personal perceptions here are of second importance, I need to state that I personally don't find these structures vulgar or ugly, but rather pretty, cheerful, as representation of hope and glory. Furthermore, using the terms does not aim to ascribe this aesthetics with specific ethics and renders the subjects not only as bad taste, but often immoral and antisocial. The usage is employed exactly for the opposite purpose, to reflect abject perception these houses might produce in the public ${ }^{6}$, and more importantly to stress its non-canonical language of informal construction in conveying independent meanings.

Treating visual material as text - as a system of meanings - opens up wider questions concerning structure and context; to uncover the structure of visual texts, this analysis will follow simple architectural levels of presentation: frontal decoration, structural elements, composition, etc, even though it will not employ the architectural theory but will employ the landscape as the framework for analysis ${ }^{7}$. As many examples will subsequently

\footnotetext{
${ }^{6}$ Some of the houses analysed in the paper are often listed as bizarre architecture in the local media, such as Motel Gajić, Šešlije which was presented as "China in Bosnia and Herzegovina, close to Sarajevo" (Car 2012).

${ }^{7}$ For the same reason, the analysis will not consult postmodern architecture. As postmodern architecture is integrative and vibrant part of professional architectural cannon, initiated with Robert Venturi, Denise Scott Brown, Michael Graves and Phillip Johnson,
} 
show, structurally houses were usually not fully completed or were slowly disintegrating already. This is why reading architectural levels (composition, production, and intervention) is used to gauge what is unfinished, hidden or ignored and disguised in the gaps. I examine how these assemblies (structure or its lack) are used to send messages to the environment. Looking at them with a driver's gaze I ask how they might be conveyed as images in a specific re-iconisation process rendering the landscape.

\section{INVOKING TRADITION, OBUDOVAC}

On the local road R462a, between the towns of Brčko and Šamac in the village of Obudovac, there is a private building that initially reminded me of a castle. This assumption, based on the towers that dominate the house's model, was soon complicated by a Serbian journalist who qualified it as "Byzantine" (Sabljić 2008). The simple rectangular base of the house is expended on the front-left corner with a circle that resembles a roller shaped tower, whilst on the right there is a smaller square that resembles a cuboid tower. The walls separating the building's spaces are built in red/ brown bricks and opened with white PVC doors and windows. The third floor partially continues with the roof, which covers the third and fourth floor. On the central right side of the roof there is an additional tower that serves solely for decoration. The towers have only been covered with simple black isolation mats without roof tiles. Behind the main building there is an additional room, a "summer kitchen", with its flat top, serving as an additional terrace, and an outer staircase. As a prominent decorative

and fully affirmed with Frank Ghery, Aldo Rossi, or Arata Isozaki and the others, it cannot be used to explain visual expressions in informal constructions without falling to the simplification. The points of iconic imaging and eclecticism, fragmented references, breaking up with the tradition and simulation might be common in both of these practices, but postmodern architecture is still formal architecture. It operates within formal codes of the project cycle, follows urban planning and has significant symbolic capital in the public, while the informal construction is excepted from any of these. More like simulation of the postmodern architecture, the informal construction analysed here is rather connected with the postmodern society. 
feature, the flat surfaces of the walls are interspersed with smaller semicircular reliefs made of patterned brick similar to those in medieval Byzantine churches. The same technique of bulging brick lines has been used to accentuate floor levels, doors and windows.

Apart from these, the building has no other decorations at present, while older photographs (Figure 1) show that the façade also contained an advertisement (in Cyrillic: Restaurant Pizzeria), a Serbian flag and airconditioning while the front yard and terrace contained tables and chairs for restaurant guests. More recent photographs (Figure 2) show that the restaurant has been replaced with a second-hand shop.

The house's PVC windows and apparent lack of clear stylistic connection between the towers show that the visual composition made a few compromises, which are additionally accentuated with unfinished works. Doors and windows that are only roughly placed in the walls, with other missing works, such as the lack of isolation on the tower roofs and basic construction of the summer kitchen, suggest the project is experiencing financial difficulties.

With its characteristic brick walls, its three towers and complex roof, this is not an ordinary vernacular house. Its mismatching towers look confusing, but its brick walls hint towards (neo) traditional churches. "Traditional" has been qualified with caution since using bricks in construction and especially in decoration is locally more associated with mediaeval Christian architecture ${ }^{8}$, e.g. it could be read as "Byzantine". However, such a style would never be used in housing, particularly bearing in mind the lack of professional design and supervision in vernacular construction. The relation to the past and to larger nationalistic trends is obvious, but has been interrupted as the eclectic combination of towers, decoration and materials gives the building a Disneyesque quality. Its reference to Serbian nationalism is additionally interrupted with symbolic interventions. While the local village church radiates with nationalist tones (e.g. the windows are coloured in the colours of the Serbian national flag), the house does not have any national

8 Byzantine can refer to a much wider set of works. The use of bricks here particularly refers to the Raška architectural school with the example of the Visoki Dečani monastery. 
Stud. ethnol. Croat., vol. 27, str. 449-478, Zagreb, 2015.

Mišo Kapetanović: Post-socialist landscape: A castle by the road

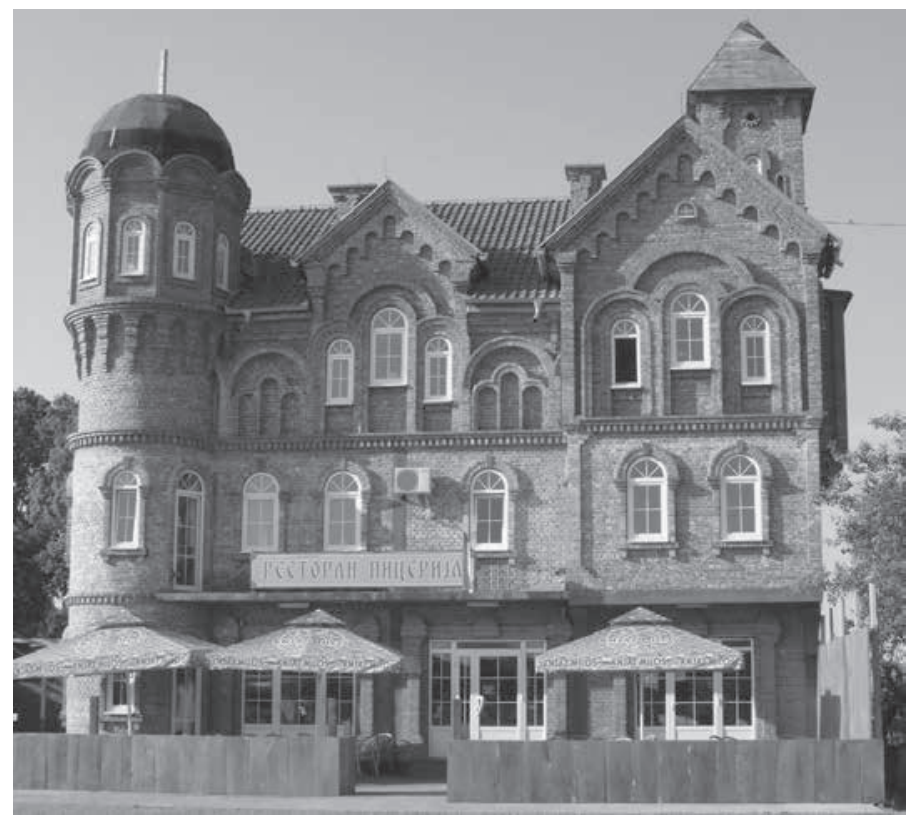

Figure 1: Restaurant "Dvor Brane Perića”, Obudovac. Photo by Milomir Stanković, 2009. Source: Panoramio. Available at http://www.panoramio.com/photo/22731513 (Accessed 12 September 2012)

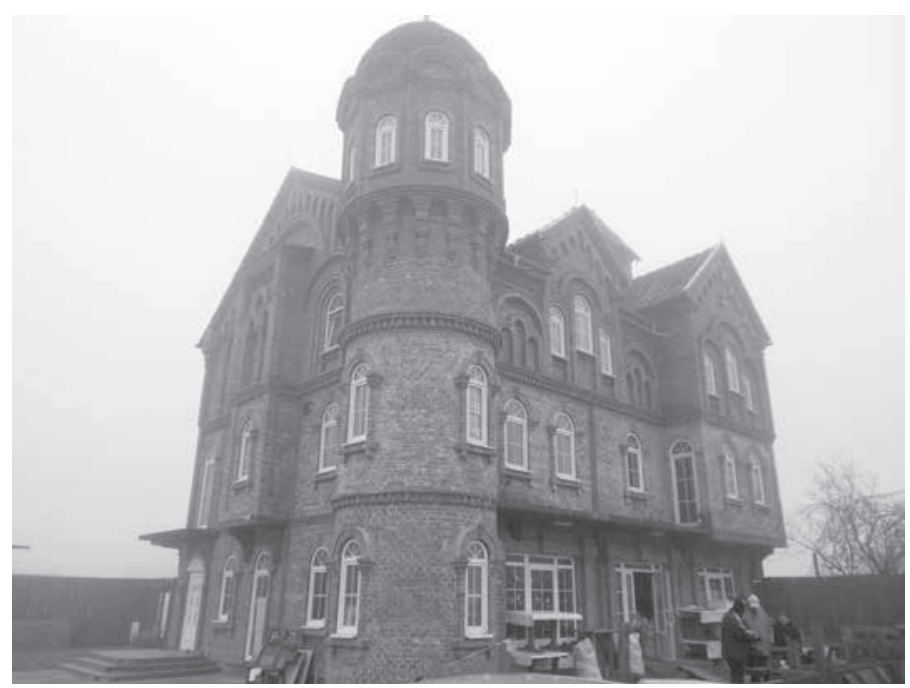

Figure 2: Obudovac Castle. Photo by Milorad Kapetanović, 2013 
characteristics any more. An older picture (Figure 1) of the house depicts a pizzeria on the ground floor with a prominent flag of Republika Srpska entity and an advertisement in Cyrillic with a flag. A more recent picture (Figure 2) shows that the new business that took over the ground floor has no decorations except for titles and advertisements written in the wider used Latin script. As the new business only appears to be moderately successful, it is plausible to assume that there was a need to play down the nationalist tone in order to attract more customers.

Of greater interest is a general intervention made in the democratisation of sacral architecture. While more prominent towers seem incoherent and misguiding, the house's walls are distinctive as regards their decoration. These decorations would be conventionally used in churches, but their usage reads more like folk stories in the online photography community. Lacking construction supervision, a situation characteristic for the postsocialist context, the designers of vernacular houses are largely free to build whatever they want. Using sacral decoration was probably a part of general ethno-national concept in conveying the house's style, which was accentuated by temporary decorations (advertisements in Cyrillic lettering locally used only in Serbian, with a flag to seal the reference). But without this literal iconography, the decoration became inoffensive "folklore" and was praised in an on-line photography community for its beauty?

\section{CROSSROAD FANTASY, ŠEŠLIJE}

Motel "Gajić", Šešlije is situated on the lot by the side of the main crossing points between the regional roads M-17-2 (between Bijeljina and Banjaluka), and the M-17 leading to Doboj, Sarajevo and Mostar. The complex is composed of two buildings, the main building serving as a motel, located centrally, and an additional building on the left side serving as a shopping centre. The buildings are connected by a joint external room in between; both are modelled as simple boxes on which extensive, mainly pink, facades have been added to the front (Figure 3).

9 http://www.panoramio.com/photo/22731513 (1 ${ }^{\text {st }}$ March 2015). 


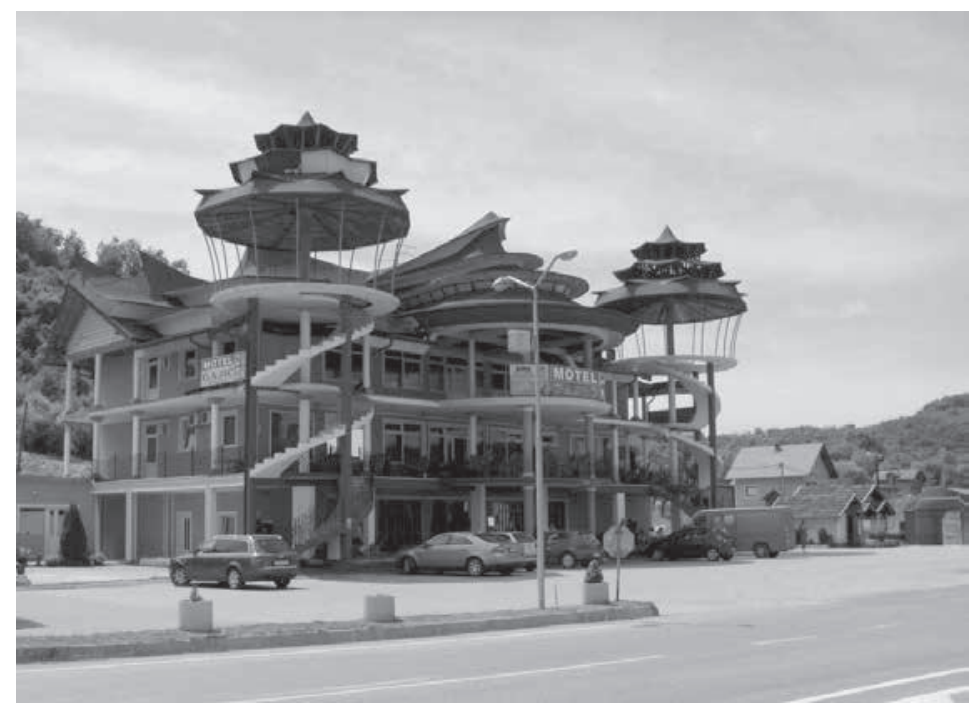

Figure 3: Šešlije (Doboj), Motel in Chinese style. Photo by Sasha Lisul, 2011.Source: Panoramio. Available at http://www.panoramio.com/photo/54332001 (Accessed 12

September 2012)

The main building consists of a ground floor and two additional floors with a simple rectangular base extended by a semicircle in front of the main entrance and connected with two circles on front-corners that define external staircases. The top of the building is covered with a complex roof, combined of several surfaces oriented towards the main roof surface above the front terrace. The walls on all three levels have been opened with PVC windows and doors that exit onto the balconies. All the balconies are supported with columns and provide independent access to the individual rooms. The external staircases on the corner are finished with additional terraces above the second floor. The building is covered with small roofs that dominate it, imitating towers. The additional building is significantly simpler with only two floors, a more modest balcony with columns, less decoration and no roof. Both buildings are lacking any kind of decoration at their rear side, while the joint space between the buildings was constructed without any protection and is clearly showing signs of dilapidation.

The smaller building, the business centre, is significantly less developed than the main one, with major works missing (visible in the lack 
of a roof and metal framework that sticks out from the top cover, suggesting that another floor is planned). The main building is missing railings on the balconies, paintworks on the left side, and lights on the second floor. The lower floors are significantly more elaborate than the upper one, presumably as they are more profitable. Similarly, the works at the front of the buildings are more developed than on the sides, while the rear has been completely ignored, thus asserting a primacy to the road perspective.

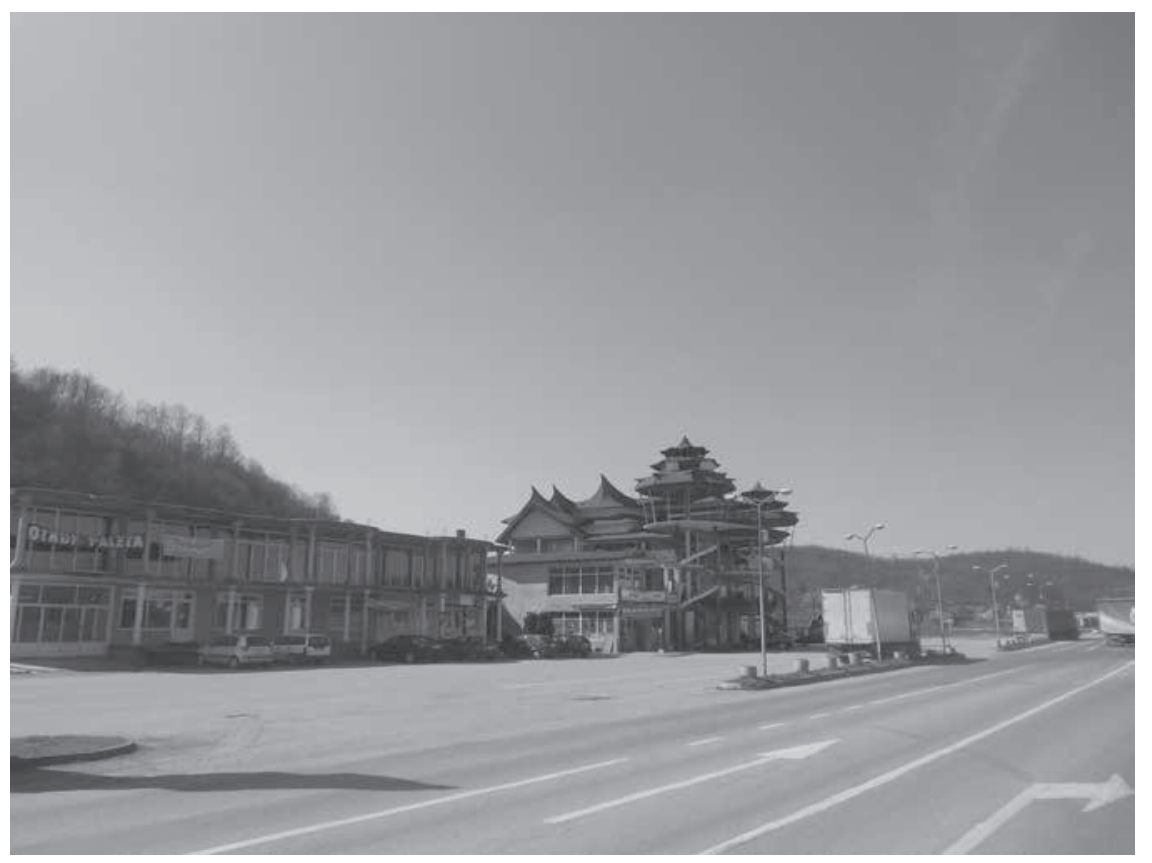

Figure 4: Šešlije Castle. Photo by Milorad Kapetanović, 2014

The visual appearance (Figure 4) of the buildings is confusing. With PVC windows and doors on dominant pink walls, a complex green roof and towers opposed to simple columns and occasional derelict spots, it is hard to identify any reference with certainty. On that note, I consulted the motel's website (motel-gajic.com) which qualifies the appearance as very marquant [markantni]. While this term was conventionally reserved for good looking Yugoslav men, it leads one to the conclusion that the prime idea of the design was to create something "out-of-the-ordinary" for 
the sake of being "out-of-the-ordinary". This strategy might explain the occasionally random composition of different elements and materials. But it is not the only tendency. As visible on the bottoms of the balconies, simple flowers drawn with a compass is used as a main feature for outer decoration (a larger one above the main entrance to the first floor and two smaller ones on the sides of second balcony bases). My assumption is that this decoration is used to create an association with a compass and architecture as a form of extravagance and good taste. Therefore the purpose of decoration was to impress and attract the drivers' gaze. The reference to a castle is incomplete and as far as I could later see, unnecessary. Browsing social media for interpretations of the building I found photographs of the building on Panoramio that describes its visuals as in a "Chinese style"10. Presuming that the shape of the roof might lead the viewer to make an association with the Forbidden Palace, it was interesting to see that the building received mixed reviews of its style with some of the commentators criticising the building's kitsch, while others praised its unusual architecture. However, it is obvious that the building's visual style does not work hard to simulate (timeless and placeless) China. It serves as an open icon for any desired interpretation while attracting drivers with its extravagance. In this strategy, iconic language is particularly useful as it leaves more space for reading into and for the interpretation of its meanings. As such, this motel offers exactly what is needed for travel, the opportunity to experience something different while being composed of familiar elements.

\section{INTERNATIONAL STYLE, KOZARAC}

The gas station "Mesić" is located along the regional road M4 (between Prijedor and Banja Luka), towards the north-western exit of the town of Kozarac (Figure 5). The irregularly shaped triangular lot on which the object is situated borders with the road M4, the local road to Kevljani and an empty field. It includes a centrally positioned main building and a temporary outbuilding (car wash), located in the right corner.

\footnotetext{
${ }^{10}$ http://www.panoramio.com/photo/54332001 (1 ${ }^{\text {st }}$ March 2015).
} 


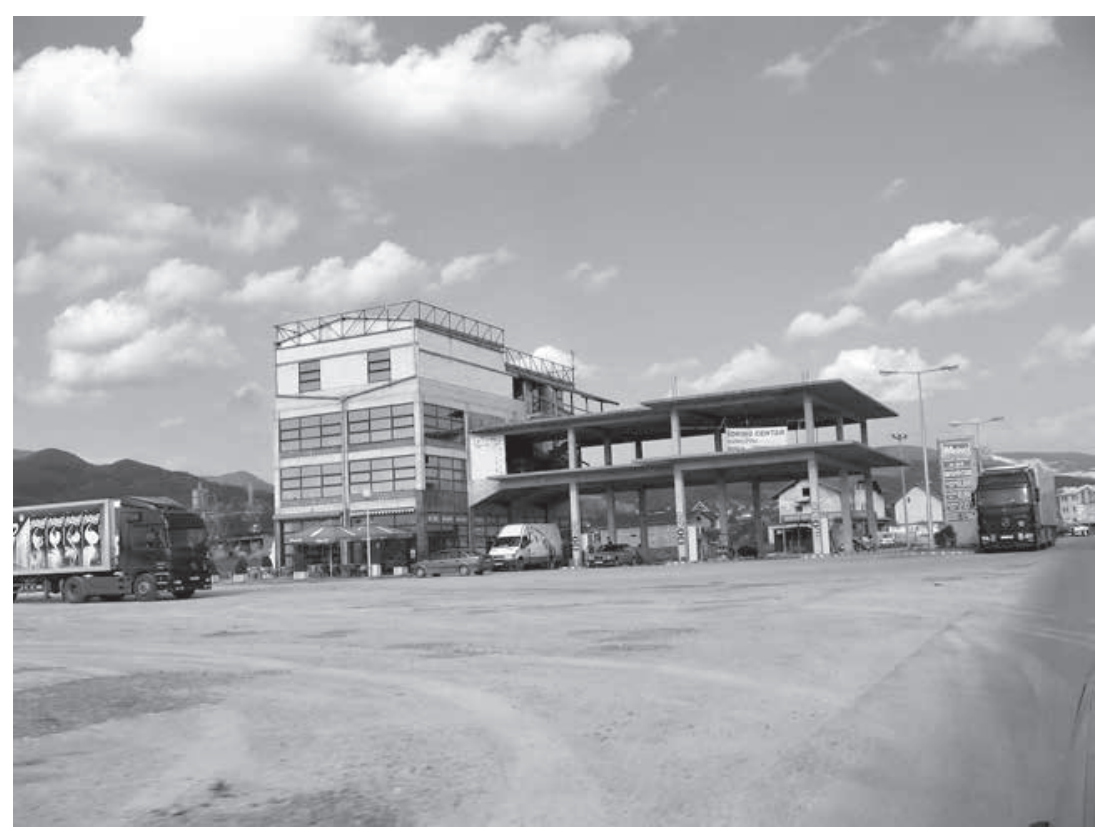

Figure 5: MESIC Pumpa - Kozarac. Photo by erdelman, 2010. Source: Panoramio. Available at http://www.panoramio.com/photo/34881737 (Accessed 3 March 2013)

The main building is modelled as a simple cuboid with extending terraces that cover gas pump isles. A rectangle-based ground floor continues with three floors and a roof construction. The fuel pump facilities consist of two isles, situated in front of the main building covered with terraces that are connected to the main building's first and second floors respectively, but are not covered with a roof. The individual floors have similar dimensions, but were built from different materials and the third floor is asymmetrically levelled, with the left side higher than the right side. The building finishes with a simple obtuse roof that follows the asymmetric top line of the third floor and ends with a small decorative metal construction. The space of the ground floor is defined with glass walls, opposite from the first and the second floor where a combination of red bricks and glass was used, while the third floor was mostly built with white concrete bricks. The terraces above the fuel pumps are not enclosed with any walls or any sort of fences. All the main building walls open with a patterning of smaller window units that cover the surfaces of the ground floor, larger parts of the first and 
second floor and a minor surface on the third floor. The building lacks any visible decorations, except for functional traffic signs and gas prices on the ground floor and a banner on the first floor advertising "ŠOPING CENTAR (Shopping Centre)".

Different materials and styles amongst the floors and spanning a large part of the building, that is still unfinished, lead one to the conclusion that construction has occurred in looser, spontaneous phases, probably when disposable income has become available. The mentioned advertisement sign suggests that the first and second floor are earmarked for use as a shopping centre, while the use of the upper floor can only be assumed to be a private area which the owner uses (judging by the shoes left in front of the door) (Figure 6).

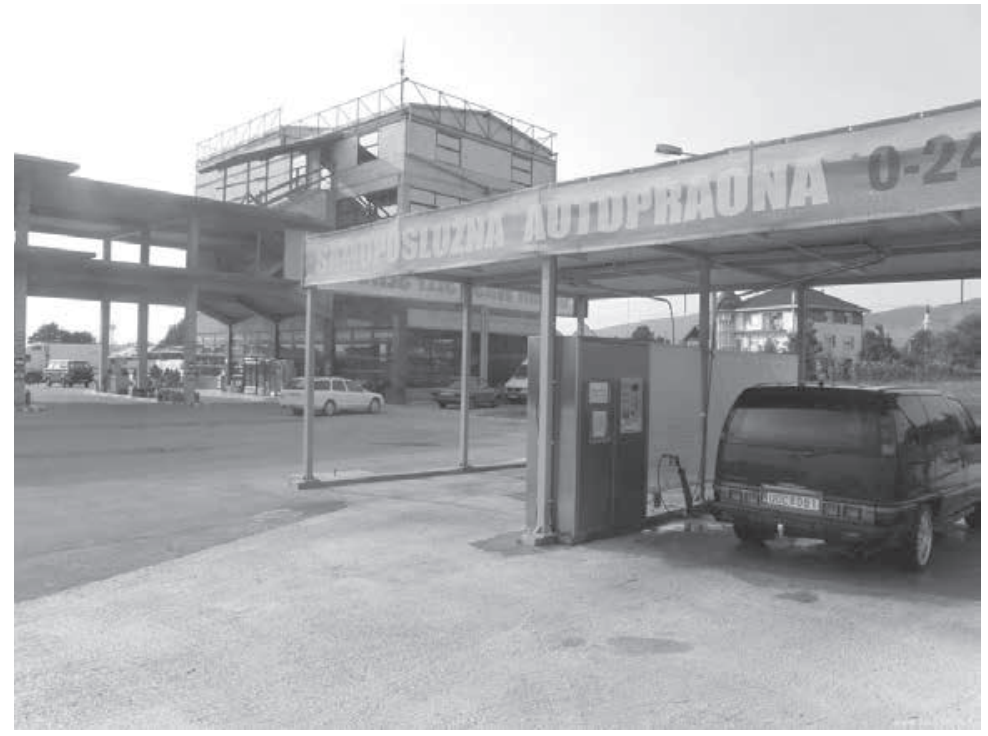

Figure 6: Mesici (www.kevljani.eu). Photo by Kevac, 2009. Source: Panoramio. Available at http://www.panoramio.com/photo/26251287 (Accessed 3 March 2013)

In contrast to the majority of neighbouring houses that are modelled on variations of the Yugoslav vernacular house ${ }^{11}$ with the

${ }^{11}$ A model known locally as "kuća na dvije vode" 
addition of bright colouring, this building is distinguished as a modern building with a petrol station. Its simple lines, rough cubical form and lack of decorations imitate the international style of skyscrapers in the financial districts of large cities. The modern architecture continues to be interpreted as progressive and developed, therefore the clear flat lines and cuboid model of the building are an obvious attempt to imitate the International style. While the style might work on the ground floor with glass walls and simple surfaces on the floors above, it loses coherence towards the top where the style is compromised with practical temporary solutions and in places completely forgotten. The Former Yugoslavia had a complex relationship with modernism and the international style that resulted in producing unique contributions (Kulić and Mrduljaš 2012). Post-war Bosnia and Herzegovina is subject to it mainly through corporate structures, as there is a lack of modern responses present in contemporary Bosnian and Herzegovinian architecture, compared to the modernist heritage of socialism (Ibelings 2010). Post-socialist modernism is mediated mostly through the proliferation of box-shaped shops and gas stations, commercial structures that are re-introducing the simple mechanical aesthetics of the assembly line. In a naïve manner, the building adapts the style merely as an architectural language for business and attempts to evoke the environment of a modern, rich city building in a sleepy Bosnian town. This attempt is interesting as part of a wider change in which houses are displaying qualities incoherent with grim post-war realities. Kozarac is frequently mentioned in the media, mainly for the war crimes that occurred in 1992 (Mihajlović Trbovc 2014). The post-war reconstruction that followed included many flamboyant examples similar to the fantastic forms presented in the Šešlije case. While the visual appearance of surroundings intensively appeals to the whole discord of ideas and images, this particular building defied this trend of luxurious colouring and shapes by referring to the ascetic simplicity of modernism, presenting its vision of progress and business prosperity. The only problem is that it quickly fails in this attempt, due to the poor economic situation which has led to construction taking place in layers. 


\section{OTHER NOSTALGIAS, BOSANSKA KRUPA}

On the eastern entrance to Bosanska Krupa, there is complex of several objects occupying an irregularly shaped lot, separated from the regional road M14 by a railway. The complex is made of two main buildings occupying the left and the centre of the lot, which are connected by an externally joined room (Figure 7).

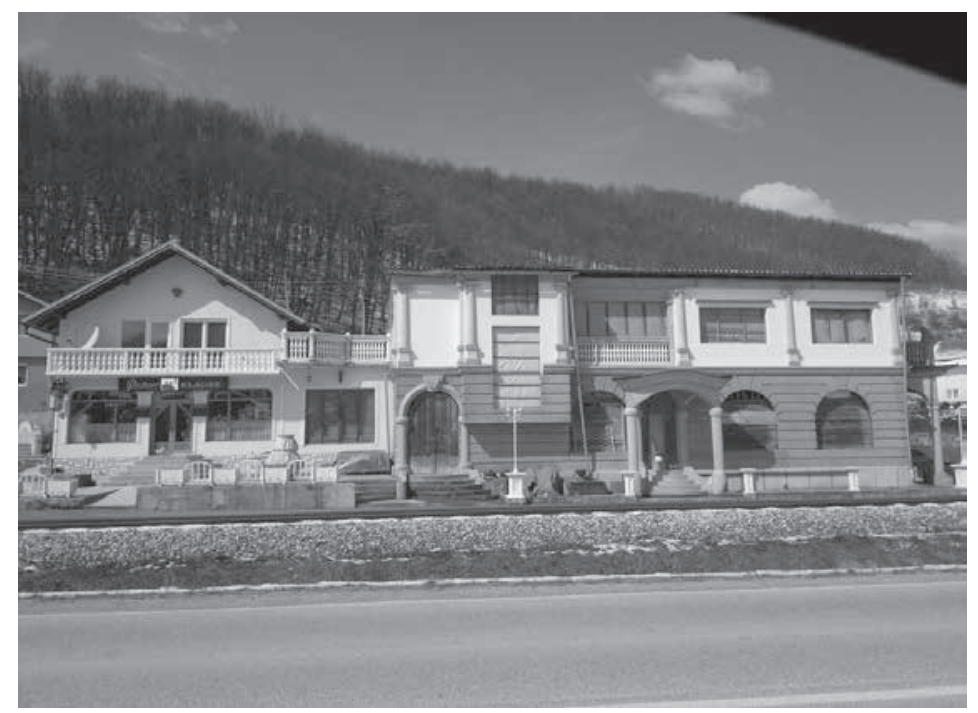

Figure 7: Krupa Bavaria Castle. Photo by Milorad Kapetanović, 2013

Moving to the centre right from there, we come to a large garden with a fountain and a tower on the right-hand side, next to the exit. The main object on the left-hand side is smaller and modelled as a simple vernacular house with a rectangular base extending across the ground and first floor and covered with a symmetric roof. The second building is twice as large, modelled as a simple cube on which a decorative façade has been applied with one surface of the roof leaning backwards to appear invisible from the road. The rectangular base of the larger building extends, on the level of the first floor, with smaller rectangular expansions on the left side likely used to create space for a staircase inside. As the building remains unfinished, spaces for windows and doors are covered with simple wooden boards and nylon sheets. Both buildings are extensively decorated. The house on the left is decorated with a beige façade and white paint linings for the doors, 
windows and balcony railings, with the ground floor bottom level covered with façade tiles imitating stone. There is an advertisement situated above the main door stating "Pschorr KLAUSE". The larger building is decorated to imitate a castle. For that purpose, its façade employs stone and brick imitation tiles on the ground floor, balcony and columns' imitations with two functional columns on the ground floor level supporting the approach cover. The garden is extensively decorated with various garden features, including smaller trees, a fountain, and a stone table and chairs, metal street lamps and concrete fences defining the entrance. The tower on the very right side is a one-floor building with a semi-circle as its base and a top balcony reminding one of a watchtower. Its walls are built with stone and are open with simple wooden doors and windows. On its outer side facing the main road there is a street sign stating: "Münchener Straße".

Without clear signs alluding to a connection with the south-German cultural space, looking at how the individual buildings have been put together, they may appear vague and confusing. The house located at the left end is not different in form from others in the neighbourhood, but its decoration, the shape of its door and windows, the colouring of the façade and identifying advertisement, directly refer to rural Bavarian pubs. The largest part in the centre stands out from the neighbourhood in terms of form and decoration. It is a structurally plain model with a complex façade, imitating stone, columns and balconies while hiding the roof, which might refer to a part of a Bavarian castle, but the reference here is looser than a direct connotation. Finally, the tower at the right clearly refers to a medieval structure, or a part of it, but again, this simplicity makes the reference wide and hard to clearly determine. Therefore, its reference is reaffirmed with the modern street sign "Münchener strasse". Other decorations include garden gnomes, fountains, tables or streetlights, which make no specific references and were probably chosen because of their appeal to the designers.

It is clear that sometimes a literal reference to Germany, presented in the randomly assembled complex, is connected to the Bosnian migrant experience. The assumption that the owners were migrant workers in Germany was supported by a number of observations. It was mainly closed during the winter and the spring, while construction works were completed in the summer (Figure 8). 


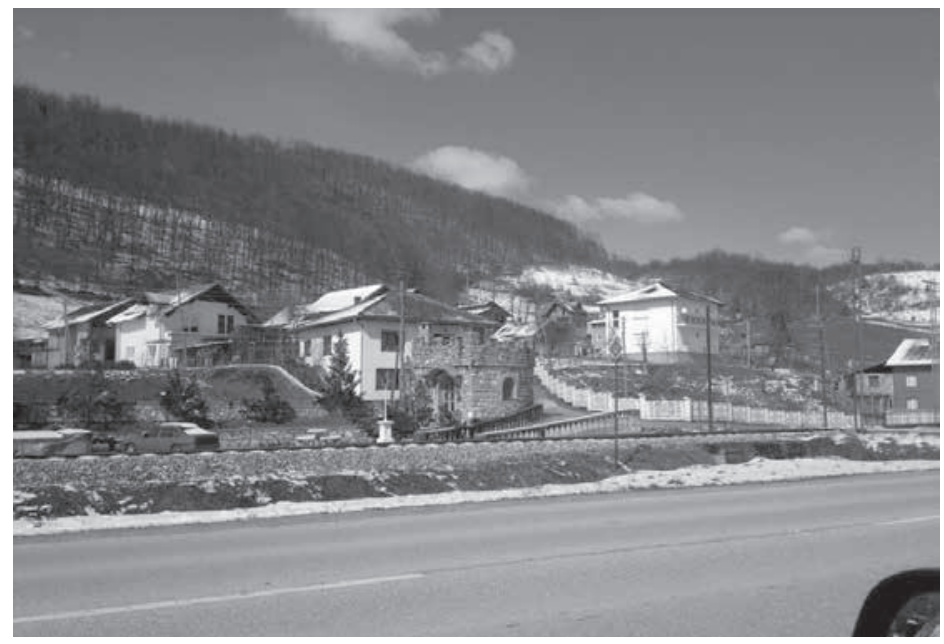

Figure 8: Krupa Tower. Photo by Milorad Kapetanović, 2013

On this view, the complex and references it creates are an exciting counterexample to the traditionalism presented in other places, primarily Obudovac. Longing for tradition, as any nostalgia, longing for "our own better past" (Boym 2001), is tightly connected with collective identities and, in the Bosnian case, nationalist ideologies. It can be used either passively as an inoffensive presentation of folklore as "the best thing we have" or as an active demonstration in the symbolic marking of territory. This house defies both of these tendencies as the tradition it longs for confuses the gaze. By building a whole theme park based on the idea of a small Bavaria in Bosanska Krupa, the complex intimately refers to the past that locally may not be considered as "our own". Germany is still the place of work and life for many gastarbajteri ${ }^{12}$, and a symbol of a lost future for war refugees that

12 As a South Slavic version of the German word for guest workers, the term gastarbajteri is narrowly used for the 1960s and 1970s labour migrants from Yugoslavia to the countries of Western and Northern Europe (Ivanović 2012). Labour migration from Bosnia and Herzegovina after Yugoslavia was additionally heightened by the war refugees in the 1990s and new labour migrants to the EU with a diverse range of skills, but here the term is used to illustrate how the traditionally alleged low cultural capital of unskilled migrants and permanent longing for their "home" society has now been made more dynamic with nostalgic portrayals of the guest society. 
were forced to return in the late 1990s. The complex personal relationship of the locals with Germany translates into the symbolism used in forming the house and creating a new longing.

\section{THE NEW SENSIBILITY OF LANDSCAPE}

In comparison to the architectural tradition of former Yugoslavia, and the relative success of socialist urban planning and socialist modernism, the appearance of the buildings might seem chaotic, apocalyptic or simply tacky. Permanently unfinished projects leave a feeling of disappointment in empty space; they are indicative of a lack of structures in design, but leave an enormous flexibility to communicate and renegotiate visions via interventions. The aesthetic quality they brought to the landscape was not only radical (e.g. uglifying), but it was almost impossible to comprehend in terms known to architectural theory, building practice or vernacular housing connected with what Roland Barthes called the new sensibility of vision (Barthes 1979:238). While this new sensibility that functions in two dimensional optics is mainly ignored, it is introducing abjection in the cultural landscape. The post-socialist landscape did not only mean the destruction of the old socialist landscapes and production of new, neoliberal structures in their place. It also entails the daring appearance of what used to be considered as kitsch, not apocalyptic and certainly not seen as progressive, but utterly unpleasant to the old gaze.

The vernacular character of the buildings does not qualify them as relevant for architectural research, but the scale of the phenomena makes them important for social inquiry. Focusing on roadside vernacular castles in the centre of the post-socialist landscapes of Bosnia and Herzegovina contrasts with the recent ways in which space in Bosnia has been viewed. Affected by a strict post-war perspective, which entailed seeing the local spaces through the gaze of war devastation, specific kinds of ruin porn was the usual frame for observing the local landscape. This gaze is not only interested in looking for devastation in a victimising and consequently pornography making, colonial way, but it also ignores any new developments that radically oppose it. With ruins retreating from the space, there is time for new perspectives. The new structures and landscape do not have to be less abject, but their kitsch and tackiness has disruptive potential. 
Not as common in the conservative housing of Europe, vernacular expressions have been well-explored in other contexts, particularly in North America where the relative absence of state control in building certain areas created a frame for naïve extravagance (Venturi, Scott-Brown and Izenour 1977). After the Yugoslav state collapsed, the war ended and disposable income started increasing amongst some strata in society, so it was to be expected that those individuals who recently became increasingly economically powerful would start to project their own designs and images onto their houses. As a combination of personal histories which inspire optimistic visions of prosperity and future, the houses seem like grandiose testimonies. The relative vulgarity of certain expressions is a consequence of the designer's modest craftsmanship, economic shifts and of the moving gaze of passing drivers and passengers. It is important to notice that these forms are not sarcastic, as irony or mockery is the luxury of professionals and consequently those that employ them, the rich. These simple, literate and open visuals are modest visions of better alternatives for society presented by non-professionals and therefore present an effect of democratisation in a landscape that might appear frightening to those used to the aesthetics of professional elites. In this process of restructuring top down architectural aesthetics by vernacular construction, two qualities seem particularly important: inauthenticity and the post-tourist gaze.

The vulgar or abject results of houses' expressions do not necessarily mean weak or no meanings are involved. These representations are compiled out of simple signs (icons, indexes) and their final product is a re-iconisation of the building itself, while the meaning can be widely negotiated. When someone builds a house heavily decorated with motifs that evoke national pride in an area with a recent past characterised by ethnic conflict, it is obvious that they are trying to reinforce the dominant politics of ethnicity. But, as it was seen in most of the cases presented, the buildings are trying to do exactly the opposite by finding their own visions of the future.

Each of the cases presented offers an image that is in discrepancy with most of the other objects in its surrounding and that visually restructure the landscape. In the first case, this was done by using ethno-national imagery that had to be modified through time from highly vocal to more inoffensive folklore presentation by abandoning identifying signatures (flag and advertisements in 
Cyrillic). In the second case, exoticism is clearly a strategy taken in order to move away from the grim reality of crossroads and truck parking lots. In the third case, an effort is made to represent the prosperous future of modernity, even though it is interrupted with an obvious lack of prosperity that extends the construction works to indeterminable deadlines. In the final example, iconic language is used to inform upon reverse nostalgia for the 'other home', the one found in the land of migration and presented to the country originally considered home. Bearing in mind that each expression conveyed in the buildings offers a particular alternative to current social difficulties in the society - nationalism, a lack of trust in state institutions and a struggling economy - each of the cases presented features an idea of an alternative.

\section{THE INAUTHENTIC POST-TURIST}

Through road-driven superficiality and imitation, the non-authenticity in the buildings rises as a quality that is awkwardly celebrated rather than played down. The majority of representations refer to distant places and times. Even when featuring traditional tropes, the visual presentations vulgarly exaggerate and oversimplify, while compositions always include unorthodox mixes of materials, elements and solutions (the use of PVC to describe the traditional in the first case, empty towers in almost all of the cases, advertisements as parts of the outer décor in all of the cases). Bearing in mind that any authenticity is constructed (Harkin 2003), the buildings oppose conventional understandings of the authentic by providing simulation. Considering that they are surrounded by sights of new corporate buildings that substitute the authentic local with programmed consumer spaces (Wood 2009), the in-authenticity of the buildings is a radical answer to unstoppable change.

All of the structures presented (even in the case of the building from Kozarac) seem to be simple boxes to which iconic facades are applied as masks; none of them are finished, they rather slowly change while communicating with the road. Visual communication, available to behold in different decorative styles, is enabled through iconic and flexible presentations and has the final purpose of merely imitating. No one is interested in authentic, elaborate reproductions by the roadside. The 
purpose of imitation is not to persuade, but to evoke. As such, houses and their businesses serve as a cheap prosthesis for fantasy by providing the distant and exotic experience of travel, even when situated on the local road. Unfortunately, as imitation works more with the imagined than the obvious, there is no actual stimulus for the buildings' physical construction to excel.

When visiting small roadside constructions evoking Byzantium, China, inner city financial districts or Bavaria, one can immerse themselves in the new environment free from the grim realities of Bosnian everyday life stranded between political insecurity and economic stagnation. While drivers and visitors to the places could certainly not be qualified as post-tourists in the context of a post-industrial late capitalist society, fragmented inauthentic buildings and their landscapes do qualify as such. In representations, these buildings clearly break with the past or their local context and simulate whatever their designers wanted, independent of tradition or authenticity. They radically break with the surroundings, the atrocities that happened around them, and produce spaces that move away from the local, even though this move seems impossible. Individual representations break with tradition by using elements that were not previously allowed or by simply choosing different elements, someone else's past, that was not given but found. Their artificiality and inauthenticity crashes down known landscapes in their small enclaves, while at the same time building new enclaves of meanings, and questioning the ideas of tradition, heritage and beauty. As such, they represent horrid, but more inclusive ideas of democracy, where those that might be perceived lesser taste are allowed to represent themselves loud and proud.

\section{CONCLUSION}

The structures presented may not be understood as pure ideas, but as practical results of ideal frameworks, an iconic language that mediates these and looser implementations of it in construction work, rendered by tidal waves of construction, negligence and reconstruction. Additionally, the primarily iconic character of visual language makes the representations appear naïve, preventing the complete immersion of the viewer, but it is precisely the openness of the iconic and shallow immersion of vernacular that opens the question of what is disruptive in it. 
In the four cases presented, it seems that the buildings and the landscapes they structure appear more chaotic than particularly able to represent clear, identifiable icons. Due to ongoing work and constant resemblance to specific elements, they start to look like each other even though they appear to be semiotic enclaves, playing hermetically with their own meanings. This common thread is tied not with particular choices regarding representation, or the theme, but with the impossibility of completion which gives the representations a fluid quality.

The incomplete nature and a convergence of creepy, ironically represented notions of the traditional, nostalgic, fantastic or modern into wider spaces deeply questions wider categories of the Bosnian, Orthodox, as well as what may be considered authenticity, or heritage. As we render Bosnian the sum of elements that we have previously related to the territory of Bosnia and Herzegovina, or connected with this society, the buildings and their wider landscapes seem deeply inauthentic and therefore unnatural. However, this process is reversible and by their existence within the territory of Bosnia and Herzegovina, they are becoming part of contemporary heritage. We start to construct them as Bosnian, since this is a reversible process.

The proliferation of these chaotic post-apocalyptic landscapes could be simplistically used to illustrate political jamming, slow economic development and/or continuous ethnic tensions that prevail in the country. But the chaotic patterns these fractal landscapes create are much more indicative of global changes, even when they sometimes appear as mockeries of it. Even when they appear in total contrast to the programmed consumer places of airports, shopping malls, hotels or other non-places (Augé 1995), they appear to be part of background developments, as spaces structured by a commercial function where basic communication is conducted in the language of economy. Even as these landscapes might seem ephemeral, without structure or a dominant ideology in the first place, they are deeply filled with meanings. These meanings are used to reinforce dominant ideologies at the level of mockery, avoidance, ignorance or abandonment, yet they serve as the detritus of a newly implemented modernity chosen after abandoning socialism. And in this new modernity, playing is sometimes the most radical choice one can make. 


\section{REFERENCES}

AUGÉ, Marc. 1995. Non-Places: Introduction to an Anthropology of Supermodernity. New York: Verso.

BARTHES, Roland. 1979. Eiffel Tower and Other Mythologies. New York: Hill and Wang.

BARTHES, Roland. 1967. Elements of Semiology. New York: Hill and Wang.

BERNSTEIN, Basil. 1964. "Elaborated and Restricted Codes: Their Social Origins and Some Consequences". American Anthropologist, 66 (6):55-69. DOI: 10.1525/ aa.1964.66.suppl_3.02a00030

BEŽOVAN, Gojko, and Slavko DAKIĆ. 1990. Alternativna stambena politika. Zagreb: Radničke novine.

BOYM, Svetlana. 2001. The future of nostalgia. New York: Basic Books.

BUCHLI, Victor, and Gavin LUCAS. 2001. "The absent present: Archaeologies of the contemporary past". In Archaeologies of the Contemporary Past, eds. Victor Buchli and Gavin Lucas, London: Routledge, 3-18.

CAR, Ivor. 2012. "Bizarna arhitektonska čuda Lijepe naše i šire”. Lupiga.com, 25 January. http://www.lupiga.com/vijesti/bizarna-arhitektonska-cuda-lijepe-nase-isire (accessed $11^{\text {th }}$ November 2015).

CRESSWELL, Tim. 2003. "Landscape and the Obliteration of Practice". In Handbook of Cultural Geography, eds. Mona Domosh, Steve Pile and Nigel Thrift Kay Anderson London: SAGE Publications Ltd., 269-283.

CZEPCZYŃSKI, Mariusz. 2008. Cultural Landscapes of Post-socialist Cities: Representation of Powers and Needs. London: Ashgate Publishing, Ltd.

GILBERT, Andrew. 2006. "The past in Parenthesis: (Non)Post-socialism in Post-war Bosnia-Herzegovina." Anthropology Today, 22 (6):14-18. DOI: 10.1111/j.14678322.2006.00449.x

HARKIN, Michael E. 2003. "Staged Encounters: Postmodern Tourism and Aboriginal People”. Ethnohistory, 50(3):575-585. DOI: 10.1215/00141801-50-3-575

HARTLEY, Walter Ong and HARTLEY John. 2012. Orality and Literacy: The Technologizing of the Word. London - New York: Routledge.

HIRT, Sonia. 2008. "Landscapes of Postmodernity: Changes in the Build Fabric of Belgrade and Sofia Since the End of Socialism”. Urban Geography, 29(8):785810. DOI: $10.2747 / 0272-3638.29 .8 .785$

HOARE, Marko Attila. 2007. The History of Bosnia: From the Middle Ages to the Present Day. London: Saqi.

IBELINGS, Hans, ed. 2010. Arhitektura u Bosni i Hercegovini 1995-2010/Architecture in Bosnia and Hercegovina 1995-2010. Sarajevo: Buybook. 
IVANOVIĆ, Vladimir. 2012. Geburtstag pišeš normalno. Jugoslavenski gastarbajteri u SR Nemačkoj i Austriji 1965.-1973. Beograd: Institut za savremenu istoriju.

JACKSON, J.B. 1984. Discovering the Vernacular Landscape. New Haven: Yale University Press.

JACKSON, J.B. 1997. Landscape in Sight: Looking at America. New Haven: Yale University Press.

KEMPENAERS, Jan, and Willem J. NEUTELINGS. 2010. Spomenik \#1-26. Amsterdam: Roma Publications.

KOS, Drago. 1993. "Predmodernost ali postmodernost “črnograditeljskih" praks”. Teorija in praksa, 5/6:453-458.

KULIĆ, Vladimir and Maroje MRDULJAŠ. 2012. Unfinished Modernisations - Between Utopia and Pragmatism. Zagreb: Croatian Architects' Association.

LEARY, John Patrick. 2011. "Detroitism”. Guernica / a magazine of art \& history. https:// www.guernicamag.com/features/leary_1_15_11/(accessed 15 $5^{\text {th }}$ January 2015).

LEŠAJA, Ante. 2012. Knjigocid: Uništavanje knjige u Hrvatskoj 1990-ih. Zagreb: Profil.

MEINIG, Donald William, ed. 1979. The Interpretation of Ordinary Landscapes: Geographical Essays. Oxford: Oxford University Press.

MIHAJLOVIĆ TRBOVC, Jovana. 2014. Public Narratives of the past in the Framework of Transitional Justice Processes: The Case of Bosnia and Herzegovina, PhD thesis: University of Ljubljana.

RADOVIĆ, Srđan. 2014. Grad kao tekst. Beograd: Biblioteka XX vek.

SABLJIĆ, Slaviša. 2008. “Obudovac, mesto 'obudovjelih žena'”. Politika, $7^{\text {th }}$ October, http://www.politika.rs/rubrike/region/Obudovac-mesto-obudovjelih-zena.lt.html (accessed $2^{\text {nd }}$ January 2015).

SAUER, Carl. 1965. “The Morphology of Landscape". In Land and Life, eds. John Leighly and Carl Ortwin Sauer Berkley: University of California Press, 315-351.

TOUQUET, Helene. 2012. Escaping Ethnopolis: Postethnic Mobilization in BosniaHerzegovina, $\mathrm{PhD}$ thesis: University of Leuven.

VENTURI, Robert, Denise SCOTT-BROWN and Steven IZENOUR. 1977. Learning from Las Vegas. The Forgotten Symbolism of Architectural Form. Cambridge: MIT Press.

VERDERY, Katherine. 1996. What Was Socialism, and What Comes Next? Princeton: Princeton University Press.

WILLIAMS, Raymond. 1977. Marxism and Literature. Oxford: Oxford University Press.

WOOD, Andrew F. 2009. City Ubiquitous: Place, Communication, and the Rise of Omnitopia. Cresskill: Hampton Press, Inc. 
Mišo Kapetanović

\section{POSTSOCIJALISTIČKI KRAJOLIK: DVORAC POKRAJ CESTE}

Rad prati proliferaciju privatnih kuća i poslovnih objekata izgrađenih uz glavne ceste u Bosni i Hercegovini, koji su modelirani da podsjećaju na dvorce. Zanimaju me promjene koje ove strukture prave u krajoliku, nove kvalitete i značenja koja upisuju u okolinu. $\mathrm{Na}$ prvi pogled u njihove nadrealne, razdragane i naivne forme očigledno je da strukture evociraju nostalgiju, egzotična mjesta i fantazije. Kroz semiotsku analizu baziranu na fotografiji pokušavam otkriti kako građevine vizualno pregovaraju postsocijalističke i poslijeratne perspektive i pojedinačne prikaze koje ove perspektive nude, te želim saznati više o novoj modernosti koja ih okružuje.

Ključne riječi: cestobraz, post-socijalistički, nostalgija, imitacija, post-turizam 